Relations industrielles

Industrial Relations

\title{
Arbitration Procedure
}

Its use in the Province of Quebec

Volume 4, numéro 8, avril 1949

URI : https://id.erudit.org/iderudit/1023543ar

DOI : https://doi.org/10.7202/1023543ar

Aller au sommaire du numéro

Éditeur(s)

Département des relations industrielles de l’Université Laval

\section{ISSN}

0034-379X (imprimé)

1703-8138 (numérique)

Découvrir la revue

Citer cet article

(1949). Arbitration Procedure: Its use in the Province of Quebec. Relations

industrielles / Industrial Relations, 4(8), 79-80. https://doi.org/10.7202/1023543ar

Tous droits réservés @ Département des relations industrielles de l’Université Laval, 1949
Ce document est protégé par la loi sur le droit d'auteur. L’utilisation des services d'Érudit (y compris la reproduction) est assujettie à sa politique d'utilisation que vous pouvez consulter en ligne.

https://apropos.erudit.org/fr/usagers/politique-dutilisation/ 
of the employers and employees, if the break is complete between capital and labour, if the economic and the social conditions are so placed, by the judicial framework, that it is not possible for them to meet and understand each other.

At the very foundation, the reform of the enterprise hits the problem of property. It is surprising to remark, on this subject, how well, since a century, the capitalist system has succeeded in passing for the uncontested defender, the sole guardian of personal property. How clever, - wolf in sheep's clothing, - to act pure, if we may put it in this way, whereas in reality in ninety percent of the large organizations, commercial and industrial, it represents what is most anonymous, most collective and widespread.

In a chapter, entitled «Property and Enterprise», Rev. Bolté defines property, enumerates its titles, then makes the applications which are necessary for the enterprise which may vary from personal property to a gathering of a capital from all over the world. The author concludes from all this, that, on one hand \& under the inspiration of economic liberalism, money is the master, and one neglects the social function inherent to property, the service inherent to authority », and that, on the other hand, if one wishes to correct this situation, make the large enterprise «a communitary reality , it is necessary to modify the wage contract by some elements drawn from the contract of partnership.

In his part, Mr. Marcel Clement, after having stood free enterprise against \&laissez-faire » enterprise, makes the necessary distinction between paternity, patronate and paternalism, analyses the structure of the modern enterprise, explains some of the solutions which can be applied to correct its faults and deficiencies. The Rev. Gerard Dion studies morality of profit-sharing while Mr. Clement shows what role unionism must play in the elaboration of structural reforms.

All those who wish really and sincerely to work at the restoration of the social order will find it profitable to read and study the book \& Structural reforms in the enterprise ». Even if it does not cover the question completely, as the authors point out, it will contribute singularly to inform, to make one think and to open new horizons.

André Roy

(L'Action Catholique)

\section{ARBITRATION PROCEDURE}

Its use in the Province of Quebec

The annual report of the Department of Labour for the year 1947-48 can be consulted with a great deal of interest. Statistics have been compiled which permit the reader to appreciate the immense effort in conciliation and arbitration which has been made without noise or much publicity by the conciliators and arbitrators nominated by public authority.

First, a rapid glance at the report of the Labour Relations Board tells us that during this year, unions have deposited 676 collective agreements covering 158,317 employees. A complementary report indicates, after taking into account agreements terminated, denounced and not renewed, that 1136 agreements are in force covering 163,548 employees.

We are not in a position to explain the wide discrepancy between the number of agreements deposited during the year and that of the agreements now in force nor can we explain the small difference between 158,317 employees covered by the agreements of the present year and 163,548 employees covered by the agreements now in force. In any case, these figures may be found on page 33 of the annual report.
Table No. 9, on pages 34 and following, classes by union affiliation, the number of agreements deposited as well as the employees covered, during the same year.

The Canadian and Catholic Confederation of Labour, Inc. has to its credit 163 agreements, covering 44,057 employees. 124 of these agreements were concluded after direct negotiations, which constitutes a very large percentage. On the other hand, 39 have passed by the stage of conciliation and 13 by that of arbitration.

The independent unions, incorporated or not, have to their credit 73 agreements covering 27,175 employees. 66 of these agreements have been concluded by direct negotiations, 7 have been referred to conciliation and 3 only to arbitration.

For the Canadian Congress of Labour it counts 71 agreements interesting 12,873 employees. Of these agreements, 50 have been negotiated directly by those interested, 20 have been brought to conciliation and 14 to arbitration.

Finally, the Trades and Labour Congress, to which are affiliated the American Federation of Labour unions, has to its credit 137 agreements, covering 40,280 employees. Of these agreements, 
110 have been signed after direct negotiation, 25 have been submitted to conciliation and 15 to arbitration.

We are a little surprised that, in totalling the arbitrations indicated in the statistical report of the collective labour agreements of the Labour Relations Board (page 33) we arrive at 79 councils of arbitration, when, if one refers to the report of Mr. Cyprien Miron, director of the Conciliation and Arbitration Department (page 62) one finds that 99 councils of arbitration have been formed during the fiscal year 1947-48. How can this difference be explained between the total of 79 arbitrations indicated by the Labour Relations Board and that of 99 arbitrations as shown by the Conciliation and Arbitration Department ?

Even if we admit that certain councils had already started to operate before the fiscal year and that others had not yet rendered their decisions by April 1, 1948, there still remains a difference of $25 \%$ which appears exorbitant to us and we would invite those interested to compare their annual report or to give the explanations that will permit an understanding of the differences noted.

In any case, it is interesting to know from Mr. Miron's report, that of the 99 arbitrations registered during the year 1947-48, 34 must be put to the credit of the Canadian and Catholic Confederation of Labour, Inc., 30 to the Trades and Labour Congress (A. F. of L.), 22 to the Canadian Congress of Labour (C.I.O.) and 13 to independent groups.

This is certainly not the same proportion that may be noted in the statistical report of the Labour Relations Board (page 33).

It is possible that all these differences, annoying to the public, which seem to be indicated by the official documents, be due to the fact that certain arbitrations organized by the government department, affected the collective agreements which could be extended to a third party or to settlements of grievances. We insist, however, that explanatory notes be given in the official reports furnished by the various departments.
The chapter about conflicts, which have arisen during the year 1947-48, does not lack interest, either. One would be surprised to learn that 80 strikes were declared (refer page 94 and following). Of this number, 27 were attributable to unions affiliated with the Canadian and Catholic Confederation of Labour, Inc., 16 to those affiliated to the Trades and Labour Congress (A. F. of $\mathrm{L}$.) and 37 to those affiliated to the Canadian Congress of Labour (C.I.O.).

The majority of the C.I.O.'s strikes have taken place in the Leather and Shoe industry. The C.I.O. made a big campaign to get hold of the Shoe industry and that of Handbags. This campaign does not seem to have given much results. The other strikes of the C.I.O. have been in the meat-packing industry.

We would invite the reader to secure this interesting report from the Publications Department of the Department of Labour, 490, Blvd Charest, Quebec. One will see some interesting notes on the nature of the conflicts, their duration, number of working days lost and methods of settlement. It is to be noted that conciliation after arbitration sfems to have given excellent results. We are not in a position to say if all the procedures provided by the law have been followed by the employers and the employees; it would be interesting if the report would indicate if these procedures were violated or not.

In sum, conciliation and arbitration procedures, in the Province of Quebec, as elsewhere, give good results when one knows enough to have recourse to them. As we said recently, on approximately 1200 agreements, negotiated during the course of a year, three-quarters or 900 , have been settled directly, by the interested parties, leaving the conciliators the care to aid in the settlement of 300 disputes.

These conciliations sometimes meet with defeat and necessitate in about one-third of the cases, the formation of an arbitration council. The majority of the arbitration awards are accepted by the parties leaving only a residue of unfortunatc cases where the parties must resort to economic force to obtain justice. 